ESJ Social Sciences

\title{
Social Entrepreneurship and Sustainable Development: The Case of Social Enterprises in Azerbaijan
}

\author{
Nazila Aliyeva \\ Khazar University, Baku, Azerbaijan
}

Doi:10.19044/esj.2021.v17n12p39

Submitted: 31 August 2020

Accepted: 13 April 2021

Published: 30 April 2021
Copyright 2021 Author(s)

Under Creative Commons BY-NC-ND

4.0 OPEN ACCESS

Cite As:

Aliyeva, N. (2021). Social Entrepreneurship and Sustainable Development: The Case of Social Enterprises in Azerbaijan. European Scientific Journal, ESJ, 17(12), 39. https://doi.org/10.19044/esj.2021.v17n12p39

\begin{abstract}
The social entrepreneurship theory is still in the conceptualization phase, as each country has individual specifics and approaches to define social entrepreneurship initiatives. The main objective of this paper is to explore the characteristics and backgrounds of social entrepreneurship from Azerbaijan's perspective, especially its importance in achieving Sustainable Development Goals. To fulfill the objective, there are a few main research questions defined: How do local social entrepreneurs use both business acumen and philanthropic principles to address social, cultural, and environmental challenges? How can Social Entrepreneurship contribute to the Sustainable Development Goals in Azerbaijan? A qualitative research method was used to gather data through a semi-structured questionnaire. It was found that local social enterprises change the structures and systems that create the conditions for poverty, and the development processes need to consider the link between social entrepreneurship and sustainable development. This paper has significant implications, especially for the stakeholders and policymakers. It indicates the current position of local social ventures about sustainable development and offers some global practices and experiences to improve and facilitate the process and attracts the attention of policymakers on the performance of social enterprises.
\end{abstract}

Keywords: Social entrepreneurship; sustainable development, sustainable business; Azerbaijan. 


\section{Introduction}

The increasing popularity of Social Entrepreneurship in recent years was not a coincidence. All began after capitalism and the industrial revolution formed today's modern and developed world, which also caused several economic and environmental problems. Over two centuries, the world's most developed countries have experienced an unprecedented generation of wealth. Nevertheless, such success is not enjoyed in all countries. The apparent gap between the class of have and have not, is rising frequently affecting severely the global economy and power. Every year, ten million people die of starvation, or hunger-related diseases, more lives taken by AIDS, malaria, and tuberculosis combined, seventy-five million children do not have access to education, women earn one-third less than male colleagues for doing the same work and compose only eighteen percent of parliament seats around the world, two and a half billion people live without access to adequate sanitation. On the horizon, it is predicted that the world population will increase up to 9 billion people in the next decades, which is triple the amount of seventy years ago. On the other side, climate change is the biggest threat with extreme weather patterns, rise in the sea level, and its impacts on existing species.

Numerous attempts have been taken to address the immense social and environmental problem. Some of those efforts have been successful, but unfortunately, most of them have failed to generate substantial progress. Finally, entrepreneurship was seen as a good solution method, because in this capitalist world, entrepreneurs are the main actors of society who can create a change and influence the economy and the whole world. Over the last four decades, "social entrepreneurship" or attempts to use entrepreneurial, private sector approaches to address social and environmental needs have emerged. Many experts believe that social entrepreneurship represents a new structure, and ideology can cover multiple challenges.

When the topic is about Social Entrepreneurship, Sustainability and Sustainable development terms will appear as a central part of it. Graham Hubbard states that the emergence of 'sustainability and 'sustainable development is the reflection of fundamental changes in global minds, which will also force organizations to evolve their approaches to measuring organizational performance.

Sustainable development will be one of the big themes of this research paper. To invest in Sustainable Development, UN member countries developed Sustainable Development Goals within the 2030 Agenda for Sustainable Development. The 18th Sustainable Development Goals were designed to contribute to the main challenges of our world and expressed in seventeen specified goals meeting conditions in terms of innovation, 
scalability, and sustainability (Hummels, 2018). Achieving these goals will demand collaborative efforts of governments, businesses, and third sector actors. However, the study mainly concentrates on understanding Social Entrepreneurship's crucial role to play in the achievement of these global goals. More specifically, a conceptual framework was designed to define how social enterprises can contribute to the. Azerbaijan participates closely in the worldwide development initiatives of the international community, including the United Nations (UN). This involvement has a great significance for learning and sharing the best practices and innovative ideas, and it has been a major factor for the successful implementation of Millennium Development Goals (MDGs) in Azerbaijan in the last 15 years. As the main actors of Sustainable Development in Azerbaijan, neither the Social Economy nor Social Entrepreneurship is clearly defined by the state. In this research, the data is explored related to the current situation and performance of socially oriented enterprises in Azerbaijan to create literature on this issue for further development of the conception and to be a push factor to increase the number of social enterprises.

\section{Literature Review}

Fully understanding social entrepreneurship is a challenge. This part attempts an extensive literature review related to Social Entrepreneurship, Social Entrepreneurs, Sustainable Development in business, strategy, and related areas.

The term 'Social Entrepreneurship' itself is seen as too broad and vague and hence many people tried to give various definitions to it (Austin et al., 2006; Bac \& Janssen, 2011; Mair \& Martí, 2006a Stevenson and Wei Skillern 2006). Overall, the definition of social entrepreneurship can be summarized as a movement for addressing social problems by catalyzing the transformation of existing ideologies. It could also be expressed that social entrepreneurship "emphasizes problem-solving and social innovation developing radical new approaches to solving old problems" (Johnson, 2000). One of the earliest statements defining social entrepreneur belongs to Gregory Dees (1998) defined one of the earliest definitions of a social entrepreneur. He proposed that:

"Social entrepreneurs play the role of change agents in the social sector, by adopting a mission to create and sustain social value (not just private value); recognizing and relentlessly pursuing new opportunities to serve that mission; engaging in a process of continuous innovation, adaptation, and learning; acting boldly without being limited by resources currently at hand, and exhibiting heightened accountability to the constituencies served and for the outcomes created." 
Generally, the definitions of social entrepreneurship can be divided into two parts: 1) nonprofit organizations with business practices, and 2) for-profit organizations working for social good. When SE is described, some researchers focused on the non-profit aspect of it (Weerawardena \& Mort, 2006; Young, 1982), while others emphasized the self-sustainability and profit generation aspects (Peredo \& McLean, 2006; Seelos \& Mair, 2005; Yunus, 2007). In the existing literature, social enterprises are characterized as organizations with the mission to address social problems in an innovative and financially sustainable way (Seelos \& Mair, 2005; Yunus, 2007). There is still a vacuum in the literature, research, and awareness about the factors that lead to success in the field of Social Entrepreneurship (Alvord et al. 2004; Cramer 2003; Desa and Kotha 2006; Mulgan 2006). Leadbeater (1997) and Thompson (2002) stress in their publications the urgent need to foster social entrepreneurs. Mair, Robinson, and Hockerts (2006) expect more research to be done in understanding how values, systems, and processes can affect the sustainability of social enterprises.

At the second level, research defines the Sustainable Development case through social enterprises. The concepts of 'sustainability and 'sustainable development' have gained global attention after Brundtland Report was published in 1987. However, sustainability can mean different things to different people and organizations. Some consider sustainability as a real commitment to green practices and aligning it to the core of the business model (Smith and Sharicz 2011). Others acknowledge sustainability as being survival. According to the study, $40 \%$ of senior managers who introduced themselves as novices on sustainability issues defined sustainability as maintaining business viability. Understanding the relationship between social entrepreneurship and sustainable development, the social impact assessment process is highly essential where the organization measures, analyzes, monitors, and publicizes the changes created by the planned activities of the social enterprise. This continuous process aims to manage and control the impact created to increase or optimize it (Urmanaviciene, 2020).

As would be expected SDGs adopted lately, research literature examining broadly its relationship with social entrepreneurship is still limited. However, there are some examples for indicating this relation. For instance, we can observe in the studies of Buzinde (2016) and Sheldon, Dredge \& Daniele (2017) how social entrepreneurship in tourism can have a highly positive impact on SDGs. Wanyama (2015) examines in his further studies that social entrepreneurship plays an important role to contribute to the SDGs, particularly the goal concerning decent work. Meanwhile, Ramani, SadreGhazi \& Gupta (2017) considers the role of SE in the achievement of SDG 6 (Sustainable Management of Water and Sanitation), 
particularly in India. In the end, Rhadari, Sepasi \& Moradi (2016), drawing attract on Schumpeterian theory, depict a canvas for the realization of the SDGs with social enterprises and social entrepreneurship which is identified as critical agents in this process.

The preliminary information - legal formation, financial tools of social enterprises in Azerbaijan within global context was overlooked through the country report by Andreja Rosandic and Mahammad Guluzade in the framework of "Social Economy in Eastern Neighborhood and the Western Balkans" research. In Azerbaijan, social entrepreneurship hasn't been legally defined, so initiatives can be implemented under these legal forms: 1) Non-governmental Organizations (NGOs); 2) SME; 3) Public legal entities; 4) Family farm associations; 5) Cooperatives; 6) Informal solidarity initiatives and young entrepreneurs.

According to Mahammad Guluzade, social entrepreneurs establish their businesses with financial support from their family, friend, or own budget, bank loan, and public funding. They also can use grant funds for the primary step to establish the enterprise. In Azerbaijan financial institutions have not internal and external incentives to fund social enterprises, therefore it makes it hard to get access to the funds from them. However, there are several key stakeholders in the Social Enterprise Ecosystem such as the Ministry of Labour and Social Policy, Ministry of Economy, State Employment Agency, Council on State Support to NGOs under the President, Youth Fund under the President, National Fund for Support to Entrepreneurs, EU Funding (Civil Society Facility, etc), ABAD and so on.

Several potential benefits and opportunities of social enterprises for Azerbaijan were discussed by Urxan Alekperov, Rajab Rahimli, Ziyafat Habibova, Murteza Hasanov in the research on "Human potential of social enterprises as a factor of sustainable innovative development in Azerbaijan". According to them, as the primary mission of social entrepreneurship is to solve real social problems, it will contribute directly to the sustainable development of the national economy. Its sustainable commercial effect will ensure the self-sufficiency and competitiveness of the business.

\section{Methodology}

This research adopts a qualitative methodological approach based on a triangulation of data sources, where the research approach implemented has been that of interpretivism, which is to gain data on the theoretical concepts, sustainability aspects, and social, environmental, and economic contributions of social entrepreneurship. The first phase of the study focused on understanding the context of the study and included interviews with social venture managers or representatives and the collection of demographics and local policies. Phase II involved observation of social enterprises' daily work 
to demonstrate their sustainable practices. The last phase included participating in seminars and workshops devoted to current developments of social entrepreneurship to discuss and provide feedback to findings.

Qualitative research was used to tackle research questions and problems from different angles to investigate perceptions (Ivankova \& Greer, 2015:65). Primary data was gathered in April 2020, from social entrepreneurs and social organizations through the semi-structured questionnaire so that the research question or problem can be answered to produce original research results. The qualitative approach was used in this study to examine respondents' views, with interviews being the method of data collection. Afterward, the data were quantified to investigate and measure attributes.

The main research questions of this study:

- How do local social entrepreneurs use both business acumen and philanthropic principles to address social, cultural, and environmental challenges?

- How can Social Entrepreneurship contribute to the Sustainable Development Goals (SDGs) in Azerbaijan?

For the data collection, a semi-structured questionnaire was used, which is an instrument that combines both quantitative and qualitative items. This approach enabled to keep the interview process more like a normal discussion of the topic and explore more relevant data than a structured interview. Interviewees can explain their thoughts without interruptions, which ensures get a better outcome from the interview. Open questions asked in the questionnaire were empirically derived from the literature based on the needs of the research, and most of the closed-ended questions were generated through the help of a pre-tested survey. Participating pretest was conducted, in which six respondents (social entrepreneurs) volunteered to express their reactions to the clarity of the question form, wording, and order before the actual survey. Mainly, the questions were used to guide the discussions around the desired themes, which was the contribution of the social enterprises to Sustainable Development. The languages used in the questionnaire were English and Azerbaijani as interviewees wish.

It is difficult to identify social enterprise where the field is in the emerging stage and wasn't legally defined. The sampling technique was using non-probability. From this point, and because there is no official list of social enterprises for the defined country, sample selection was based on the use of snowball sampling, by asking participants to propose names of other organizations. Sample members were selected based on their knowledge, relationships, and expertise regarding a research subject. Twenty-five expert 
social entrepreneurs were selected as samples. Although the sample size is small, it represents the population, because this field is in its emergence phase (but developing so fast), only a few entrepreneurs could introduce themselves as social entrepreneurs. Interviews and questionnaires were conducted via e-mail, telephone, or face to face.

Analyzing qualitative raw information is an active and interactive process. As data analysis methods, narrative analysis, and content analysis were used. Narrative analysis as one of the qualitative data analysis methods was used to analyze the data which is gathered from personal interviews. Information was sorted-out and reflected up, enhanced, and presented in a revised shape to the reader. The other method was content analysis for interpreting documents, the text of different formats, pictures, audio, and videos. Later, the gathered data was read extremely carefully to derive codes. The process involves highlighting some of the words that are important for exploring the concept and primary impressions and opinions about the data were expressed. This process continues systematically, and labels for codes reflecting multiple critical thoughts start to emerge. Finally, the codes are categorized based on the relationships and linkages of the codes (Hsieh \& Shannon 2005). Data analysis started soon after conducting the first interview.

\section{Findings and Research}

Social Entrepreneurship is a new phenomenon in Azerbaijan with growing interests from academics, civil society members, policymakers, and practitioners. This is also a reflection of global trends as social impact and sustainability are gaining worldwide popularity. As well as, the consequences of the global financial crisis, the decline in oil prices and, national currency devaluations demanded new economic reformations. The government's attention increased more on the non-oil sector and SME development, reducing unemployment and increasing the welfare of the population at large. In this matter, as we experience the success stories of Social Entrepreneurship in the world, especially in third-world countries, we begin to wonder about its current implication in Azerbaijan. Focus on the non-oil sector and SME development encourages further growth of the welfare of the people in the next years. This process seems less operational on a community and regional level, and therefore Social Entrepreneurship has more potential to perform in this niche. Today several modern challenges (economic, social, demographic, human, ecological, etc.) actualizing the creation of social enterprises trigger more rapid implementation of the "Transformation of black gold into human capital" conception stated by the President of Azerbaijan Republic. In this case, establishing organizations (Community Based Organizations: Human Development and Sustainable 
Income Generation Public Unions) based on local human potential and their sustainable incomes can be very supportive in addressing social-economic problems, like as ending poverty, establishing new workplaces, gender equality, preventing labor migration, protecting family integrity, increasing awareness and abilities of people, mobilization of local renewable resources and providing sustainable development.

As social entrepreneurship field is completely new and not legally defined yet, the total number of social enterprises has not been defined. To collect information, 25 enterprises were selected based on these features which helped me to identify them as "social enterprises":

- Having an economic, social, cultural, or environmental mission that provides a social or environmental benefit

- Selling goods or services to fund their mission

- Deriving a substantial portion of the income from trade

- Using the majority of profit/surplus in the fulfillment of their mission.

From the data collected through questionnaires conducting in Azerbaijan, it was found that the majority of the founders involved in the study were individuals (52\%) (male and female at the same rate) and fewer corporates $(48 \%)$. The status of respondents were primary social enterprises with several numbers of employees, and individual social entrepreneurs with little difference compared to it.

So far, any legislation or targeted public policies are not adopted for defining social entrepreneurship. Most of the interviewed respondents had difficulty in identifying their company as a social enterprise. The tables below represent the result regarding the legal structure of the respondents. Of the respondents, regarding the structure, the majority of $n=15(62 \%)$ were SMEs, $\mathrm{n}=7$ were Informal solidarity initiatives and young entrepreneurs and $\mathrm{n}=2$ were NGOs. The reason these NGOs selected was their social business servicing to their mission. Finally, there was $n=1$ Public Legal entity.

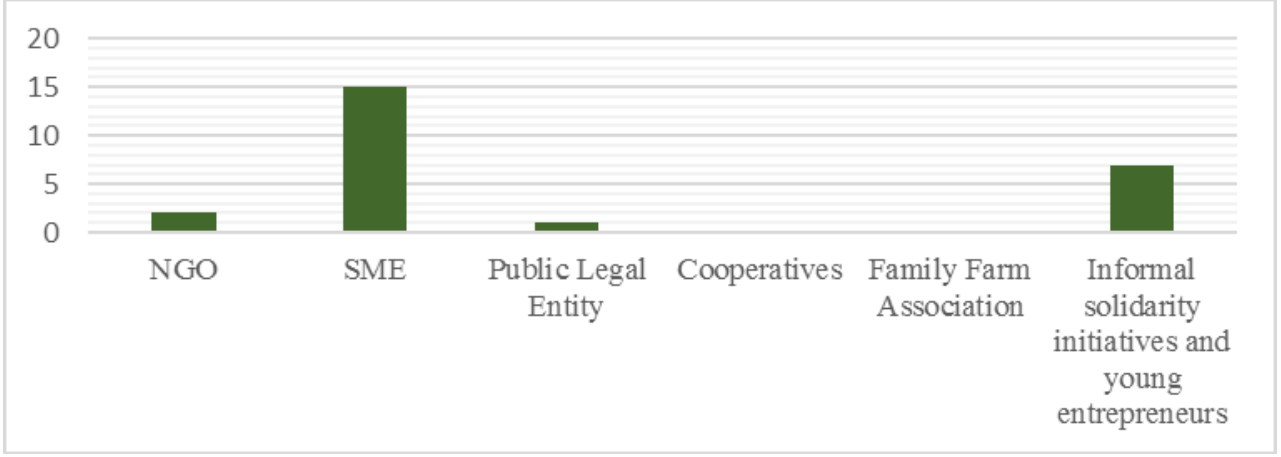

Figure 1: Form of the legal structure 
NGOs and SMEs, more than other mechanisms of entrepreneurial activity, can be effectively used because of their limited scope and mobility of activities towards the development of human potential. But still, these legal forms do not completely reflect the mission of social enterprises. Traditional NGOs seek grants and donations to conduct their missions and need to take care not to compromise their values or those they are trying to do in favor of economic prosperity. Youth, a lack of professionalism, and inexperience in operating alongside other businesses are common problems that prevent NGOs from functioning effectively. Small businesses have the opposite flaw- they often start with social purposes in mind but then abandon them in favor of becoming a profitable business.

In this research, we observe a clear increase in the number of social enterprises. Within the time frame in providing the country with social activities, it was found that social enterprises began to increase in Azerbaijan after 2011, social entrepreneurship began to get popularity and attract more interest especially in 2017. The main reason for this increase is seen as failures of NGOs and philanthropies, and success stories of global social enterprises.

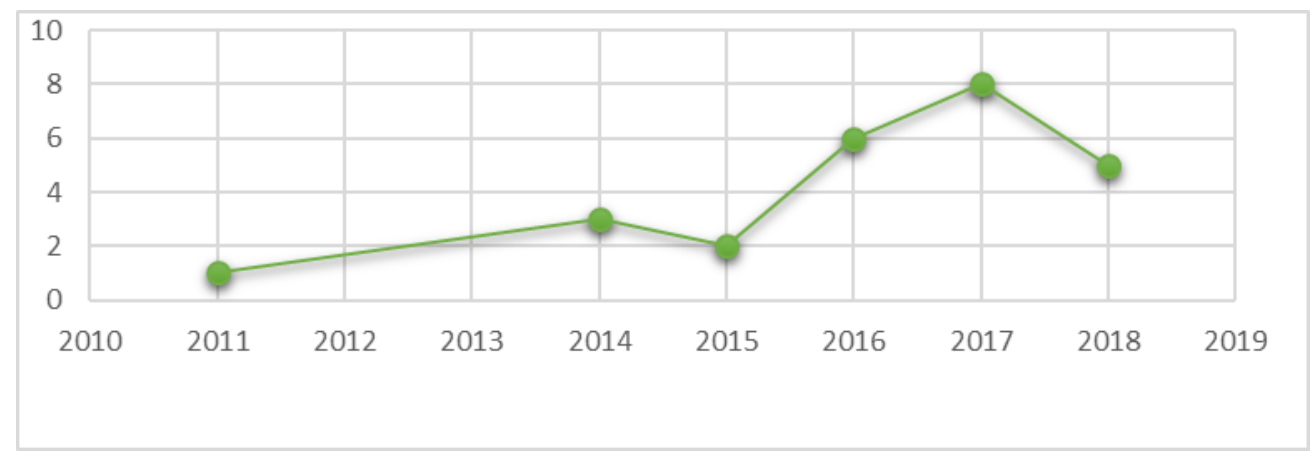

Figure 2. Years of Establishment 
Respondents were also asked about the forms of finance and investment receive besides their income. Most of them mentioned that for their internal social activities, they do not get any grants or donations, mainly they organize the activities through bootstrapping, however certain projects and additional programs are fully financed.

Equity or equity-like investments

Concessional loans (loans with below-market

Grants from foundations

Grants from Government

None

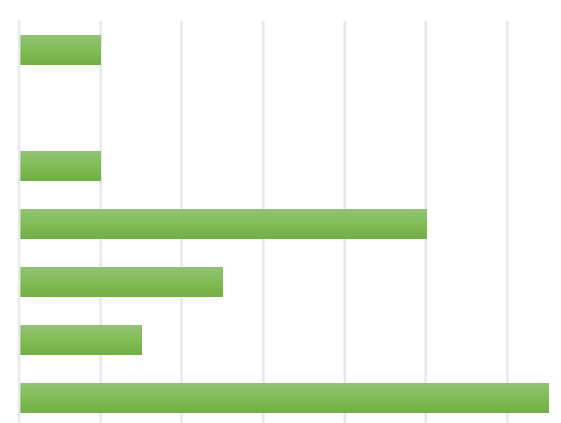

0

\section{Figure 3. Finance and Investment}

Profit distribution is also compatible with international standards, mainly it is reinvested into the organization and its development activities as described in the graph.

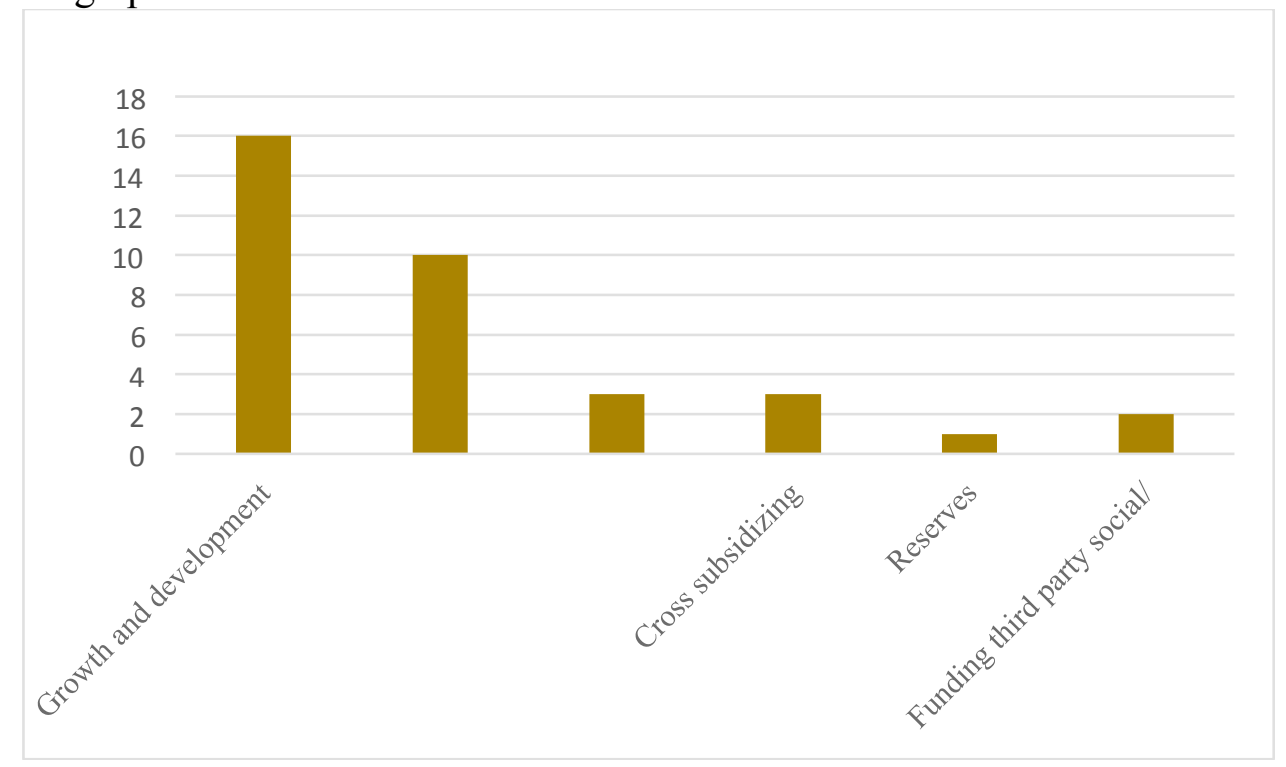

Figure 4. Profit Distribution 
To understand the concept well, it is also important to understand the motivations of entrepreneurs to start a social business. According to the answers of the majority of respondents, the main reason why they choose to become social entrepreneurs is mainly related to their values: dignity, access to opportunity, transparency, accountability, equity, and empowerment. The interviewees expressed their passion for building social value and solving people's problems who are less fortunate and keep their social mission in front of their activities. They showed the willingness of having a business as morally and ethically as possible and which will represent their principles and values. Interviewees wanted to combine the job that they enjoy with altruistic motives. One of the other main reasons was the "feeling proud of what they are doing" and "feeling like a useful person for their society."

This study also allowed to define the sectors that participants undertake social activities in the country, and the results show that the majority of $\mathrm{n}=10$ (22\%) respondents focus their activities on "Training and Development". The results also show that another key sector of activities undertaken by respondents was "Social Services" with $n=9(20 \%), n=3(6 \%)$ focused "Health", and "Religion" accounts for $\mathrm{n}=0$, "Education and Research" $\mathrm{n}=4$ (9\%), "Law, Advocacy and Politics" $n=0$, "Business and Union" $n=5(11 \%)$, "Environment and Housing" $n=7 \quad(15 \%)$, and "Cultural $n=3 \quad(6 \%)$, "Voluntarism" $n=5(11 \%)$. Social enterprises have to refocus their attention in supporting local people to handle their issues by educating them concerning the issues faced such as health, nutrition, access to medical care, maternal and child health services and establishing a variety of economic projects such as cooperative micro-enterprises, savings associations, adult literacy classes, job training, and job transfer programs to, directly and indirectly, support the economy (Lombard \& Strydom, 2011:330).

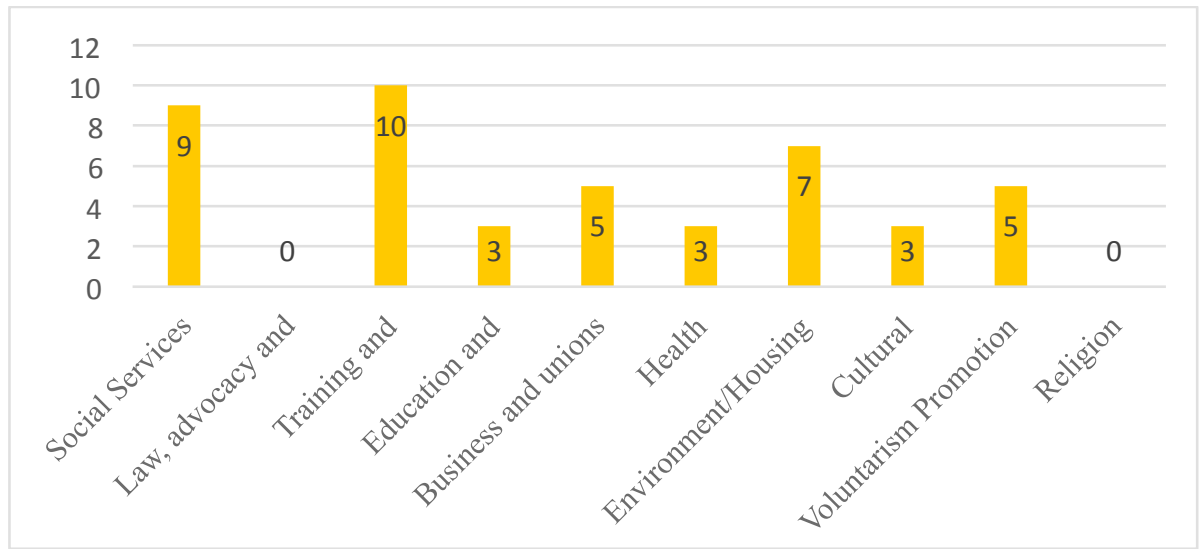

Figure 5. Sectors of undertaking activities 
The result shows that, of the respondents, a wide range of their services was received by "People in the community" and "People with low income" which respectively representing $\mathrm{n}=10 \quad(22 \%)$, and $\mathrm{n}=8(19 \%)$; "Family" n=8 (19\%); "People with employment barriers $\mathrm{n}=5 \quad(12 \%)$; "Disabled people" and $n=6$ (14\%); "Student" $n=6(14 \%)$.

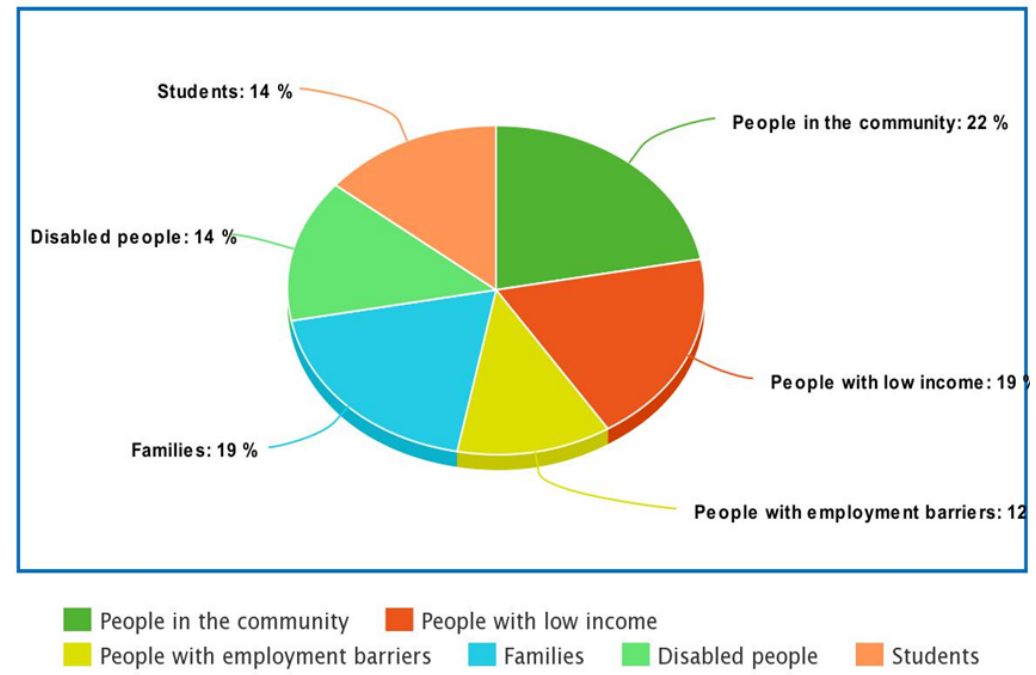

Figure 6. Beneficiaries

A significant issue facing enterprises is scaling the impact. In the social entrepreneurship context, scaling is described as 'increasing the impact a social-purpose organization produces to match better the magnitude of the social need or problem it seeks to address' (Dees, 2008). To achieve sustainable impact, there should be a more exact measurement, and calculate impact over investment. Advanced tools should be used to describe the company and the ecosystem that surrounds it because the economic evaluation of the social impact is necessary for social enterprise decisionmakers, so they can improve the effects of their actions internally and externally, even when reflection on good practice is not perceived as urgent (Iannaci, 2020).

The result from the study shows that the majority of respondents $\mathrm{n}=21(84 \%)$ measured the outcomes of their activities, and the minority of $\mathrm{n}=4(16 \%)$ do not measure their outcomes. From the result, it was shown that the respondents, in general, measured their outcomes throughout the continuous assessment, social media metrics, google analytics, monitoring, interviews, and the use of evaluation forms, follow-up forms, and feedback forms. According to those methods, participants provided numbers to illustrate how many people they have trained, have placed in employment, or received their services. The result from the respondents shows that in 8 years, more than 16264 people in the country have been trained by the 
respondents. The result also shows that 31415 people have received respondents' services in the average time of 8 years and 892 people were placed in employment. Respondents $\mathrm{n}=25(100 \%)$ also answered that they regularly improve existing programs in terms of quality and quantity. The result indicated that generally, the respondents improved existing program quality by supervision, acquiring international experience, increasing diversity of activities, service training, research, seeking support to the community, and employment of new social workers.

To understand their comprehensive contribution to society, the impact of the social activities on the beneficiaries was investigated. Based on the measurement systems, respondents indicated that their activities had brought a direct positive change in children's development who had initial physical and mental disabilities. From the respondents, the difference made through their social activities was reducing poverty by applying intensive training and attaining employment. Many people were provided with the job in the cultural and agricultural sector in remote regions and they already didn't need to leave their villages to cities to make money. The research revealed that in the country there are many initiatives on children and people with disabilities. They are involved in many cultural, educational activities, which accelerated their integration into society and make a friendly environment, and earns monthly income.

The result also shows that specific impacts such as an increase in the center, development of skills, transformation, family relationships, and parenting skills could be notified in the country from respondents' activities.

Research also demonstrated how their activities trigger sustainable development in the country. Of the respondents, $n=10(30 \%)$ said their activities trigger development in the country they operate by bringing awareness and change through acting on the information provided on different social, environmental issues, stimulating motivation and determination, promoting social entrepreneurial activities, supporting and empowering humans in their efforts to build an equitable and sustainable society for all to exchange knowledge, skills, and abilities (A). $n=11(33 \%)$ said their activities trigger development by increasing employment opportunities in regions and rural areas, to raise their social and public welfare, moreover, bringing organizations and employee candidates together creating work opportunities driving economic development (B). To improve development in the community, the research shows a common result as the majority of the respondents $\mathrm{n}=5(15 \%)$ stated that they can improve development sustainably in the country they reduce the unemployment problem of people with special needs and to ensure and accelerate social integration of the persons with disabilities (C). Respondents $n=7$ (22\%) also pointed that, their activities driving responsible consumption, promotion of 
recycling, saving the trees, cleaning up streets of Azerbaijan from paper waste, etc., contribute to the ecological aspects of SDGs (D). Preparing innovative and effective solutions to environmental problems in urban planning is also mentioned as one of the major activities.

\section{Triggering Sustainable Development}

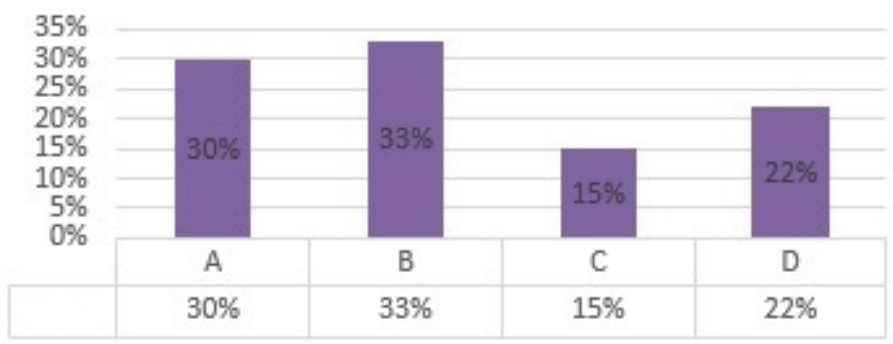

\section{Figure 7. Activities triggering SD}

After considering sectors that social activities have been taken, impacts on beneficiaries, and the activities that trigger Sustainable Development, this graph is designed to see which SDGs were mainly aimed to achieve by social enterprises in Azerbaijan:

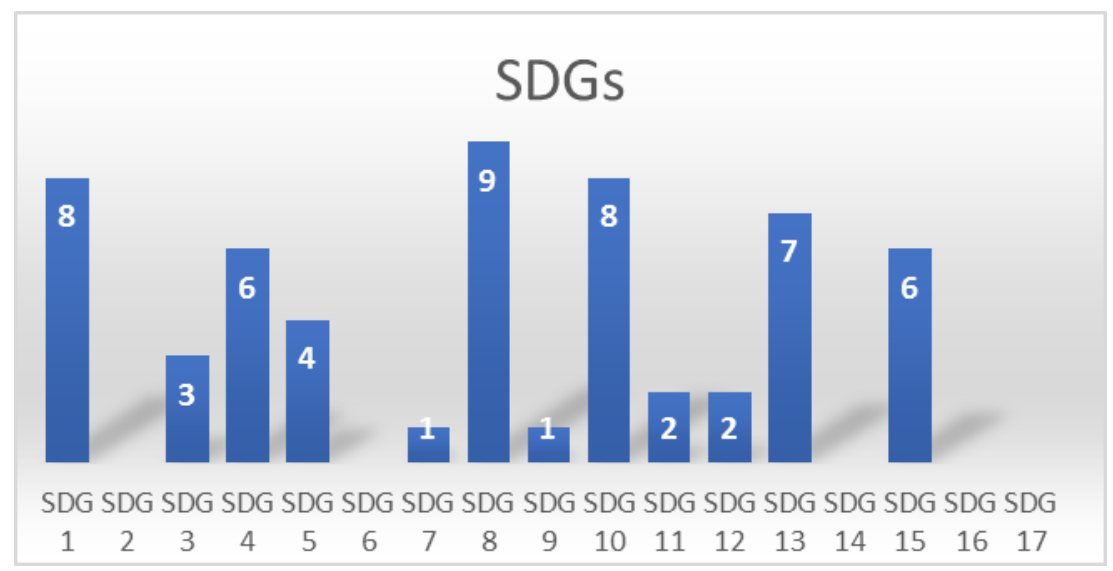

Figure 8. SDGs that contributed by Social Enterprises 


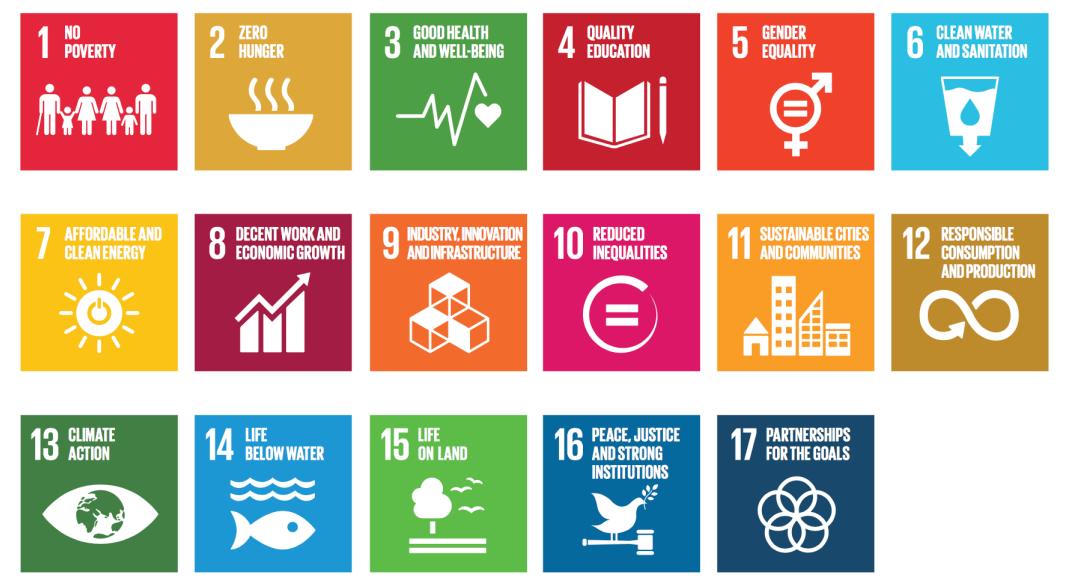

Figure 9. Sustainable Development Goals; Source: United Nations 2030 Agenda (2016

\section{Conclusion}

The purpose of this study was to understand the relation of Social Entrepreneurship to Sustainable Development and research its implication for Azerbaijan. There was a lack of current research papers on the situation and contribution of social enterprises in Azerbaijan.

The article focused on the sustainability features of social ventures. Research showed that the idea of business sustainability moves beyond economic, social, and environmental efficiency and shifts toward effectiveness (Dyllick and Hockerts 2002; Young and Tilley 2006). McDonough and Braungart (2002) argued that sustainable businesses should be designed to enhance the well-being of society while generating economic value. To build a sustainable social venture, there should be a minimum dependency on donors, financing based on multiple funding; the scalability of the business model, and a strategy for diffusing social innovation and deepening impact over time.

This study aimed at answering the main research question: How can Social Entrepreneurship contribute to Sustainable Development? From the data collection, it became evident that the most active social enterprises were located mainly in the capital city -Baku, however activities of some covered multiple regions of the country. They range from big companies having a big group of employees to individual initiators. As currently, it is hard to get registered as NGO, social enterprises were mainly registered as SMEs. In this way, they make a profit and compete with other commercial organizations in the market, but their main difference is having 
social/environmental missions as their core of activities. The purpose of the activities of involved SEs in this country was laid in general to develop the quality of life by providing comprehensive care and support to the most vulnerable, and strive to improve the quality of health, education, unemployment, provide training, educating and facilitating communities in different activities such as creating workplaces, organizing training and developing children in creating space for them to develop talent and realizing their dreams through those activities. According to respondents' responses, primarily SDG-8 (Decent Work and Economic Growth), SDG-1 (No Poverty), and SDG-10 (Reduced Inequality) are mainly contributed by Azerbaijani social enterprises. Social enterprises can manage risks better, differentiate themselves from competitors, secure access to needed resources, strengthen supply chains and predict market demand better, if they align themselves with the SDG and get a better understanding to apply them.

Finally, Social enterprises deliver social and environmental value, while operating financially sustainably. They solve social/environmental problems through products or services they offer, or they sell traditional products or services in a way that does not harm people or the planet. Social entrepreneurship is a new level with both philanthropic and commercial elements. Therefore, they fit totally in the perspective of sustainable development when they feature, sometimes as a priority, the social and environmental concerns in their economic objectives. However, social enterprises should align their strategies with SDGs to help their community, and eventually, the world to achieve Sustainable Development. The research shows that social enterprises have the potential to contribute to several SDGs at the same time. Each of these goals has indicators that help measure the result of company efforts of impact. So, direct alignment of the organizational objectives with these goals would help them to operate more determined and target-oriented. 
This paper offers several significant contributions as:

- Facilitates more understanding on the performance of Social Enterprises and their importance for Sustainable Development, especially from Azerbaijan's standpoint;

- Contributes to the body of literature and fills the knowledge gap about the contribution of SE to SDGs;

- Encourages the entrepreneurs to align their business strategies with Sustainable Development Goals to build financially and socially sustainable company, keep up with global priorities and demonstrate the commitment to global goals;

- Attracts the attention of policymakers on the performance of social enterprises;

Nevertheless, the outcome was satisfactory, the paper also has several limitations. Since the number of social enterprises is relatively small, the sample size was insufficient for the comprehensive statistical measurement. On the other hand, it was one of the first articles dedicated to social entrepreneurship and SDGs from Azerbaijan's perspective, therefore the local literature was limited to cover the topic.

Future research should also cover sustainable aspects of entrepreneurship in general in Azerbaijan. There is a gap in knowledge if companies understand the sustainability concept in their practices, and explore the ways how to improve sustainability from inside and outside of the organizational activities. This increasingly complex environment requires a new blueprint for entrepreneurship, with resilient strategies, effective governance models, and new management approaches to create a global economy that delivers on the promise of prosperity for all in a world with finite resources. We need a business model that will have zero impact on the environment and should not be at the cost of posterity. The future lies with firms that internalize stakeholder inclusivity, resource efficiency, and environmental conservation as key elements in their core business strategy and process. Therefore, not only social enterprises should struggle for sustainable development, but also all business models should take more sustainable steps. Next research should focus on the awareness of entrepreneurs with the conception of sustainable development. 


\section{References}

Alter, K. (2007). Social Enterprise Typology. Virtue Ventures LLC. Retrieved from http://rinovations.edublogs.org/files/2008/07/setypology.pdf Anja König. (2013). Social and Green Entrepreneurship Survey in Turkey Retrieved from the blog posted under the Social Impact Markets \& Policies project at http://www.socialimpactmarkets.org/blog/.

Andreja Rosandic \& Guluzade, M. (2018). Social Economy in Eastern Neighbourhood and in the Western Balkans - Country report - Azerbaijan Abil Bayramov. (2019) Sosial Sahibkarliqla Bağli Beynəlxalq Təcrübə Və Onun Azərbaycanda Tətbiqi Imkanlari

Ashoka Innovators for the Public. (2000) Selecting leading social entrepreneurs. Washington, DC. Retrieved from $<$ http://www.ashoka.org $>$. Boschee, J. (2008). Social Entrepreneurship: The Promise and the Perils. In Social Entrepreneurship: New Models of Sustainable Social Change, edited by A. Nicholls, 356-390. Oxford: Oxford University Press.

Dees, G. (2012). A Tale of Two Cultures: Charity, Problem Solving, and the Future of Social Entrepreneurship. Journal of Business Ethics, 111(3), 321334.

Emerson, J., \& Twerksy, F.(Eds.).(1996, September). New social entrepreneurs: The success, challenge, and lessons of non-profit enterprise creation. San Francisco: Roberts Foundation, Homeless Economic Development Fund.

Humberg, K. \& Kleemann, L. (2014), -Enhancing the contribution of social business to sustainable developmentll, Development Co-operation Report 2014: Mobilising Resources for Sustainable Development.

Hummels, H. (2018). The 18th Sustainable Development Goal: Social Entrepreneurship in a global society

Iannaci, D. (2020). Reporting tools for social enterprises: between impact measurement and stakeholder needs. European Journal of Social Impact and Circular Economy, 1(1b), 1-18.

Mair, J. and Marti, I. (2006). Social entrepreneurship research: a source of explanation prediction and delightl, Journal of World Business, 41(1),36-44.

Martin, R. L., and Osberg, S. (2007). Social Entrepreneurship: The Case for Definition, Stanford Social Innovation Review, Spring: 28-39.

Nikolaos Apostolopoulos, Haya Al-Dajani, Diane Holt , Paul Jones , Robert Newbery (2018) Entrepreneurship and the Sustainable Development Goals U. Alakberov, R. Rahimli, Z. Habibova, M. Hasanov. (2018) İnsan Potensialina Osaslanan Sosial Müəssisələr Azərbaycanda Davamli İnnovativ İnkişaf Texnologiyasi Kimi- - Bakı: Azərbaycan Respublikasının Prezidenti yanında Elmin İnkişafı Fondu, 2018. - 184 səh. 
Urmanaviciene, A. (2020). WISEs' Social Impact Measurement in the Baltic States. European Journal of Social Impact and Circular Economy, 1(2), 4875.

Seelosa, C., and Mairb, J. (2005) Social entrepreneurship: Creating new business models to serve the poor, Business Horizons 48, 41-246

Siri Terjesen, Jan Lepoutre, Rachida Justo, Niels Bosma and the Global Entrepreneurship Research Association (GERA). (2011). Global Entrepreneurship Monitor Report on Social Entrepreneurship Executive Summary

Smith, P., and C. Sharicz. 2011. The Shift Needed for Sustainability. The Learning Organization 18 (1), 73-86.

Yunus M., Moingeon, B. \& Lehmann-Ortega, L. (2010), Building Social Business Models: Lessons from the Grameen Experiencell, Long Range Planning, 43:308-325.

Young, W., \& F. Tilley. 2006. "Can Business Move Beyond Efficiency? The Shift Toward Effectiveness and

Ziyafat Habibova; Elmira Zeynalova Human. (2018). Potential of communities and social entrepreneurship as a factor of sustainable innovative development in Azerbaijan. The Business and Management Review, 9(4) 